\title{
Ethno-mycological study on wild mushrooms of Vulkepani Community Forest, Rupandehi District, Nepal
}

\author{
Hari Prasad Aryal ${ }^{1 *}$ and U. Budathoki ${ }^{2}$ \\ ${ }^{1}$ Institute of Agriculture and Animal Science, Paklihawa Campus \\ Tribhuvan University, Bhairahawa, Nepal \\ ${ }^{2}$ Central Department of Botany, Tribhuvan University, Kirtipur, Kathmandu, Nepal \\ *E-mail:hariprasadaryal06@gmail.com / hariaryal6@yahoo.com
}

\begin{abstract}
The samples collected from the study site, represented 13 genera of Basidiomycetes belonging to 7 orders, 12 families and 21 species. The dried specimens are housed in the Tribhuvan University Central Herbarium (TUCH), Kirtipur Kathmandu, Nepal.
\end{abstract}

Kew words: Basidiomycetes, macrofungi, mushroom diversity, indigenous mushroom, nutritive value

\section{Introduction}

Macro-fungal studies have long been of interest to scientists in the world for their significant roles in forest ecosystem, human life, their use in the pharmaceutical industry, and the mass production of cultivated fungi in the food industry, as well as their vital role in biodegradation (De Boer et al., 2005). Many studies have reported that the Basidiomycota account for most of the lignocelluloses decomposition in leaf litter (Miyamotto et al., 2000). The investigation and study on mushrooms of Nepal started since $18^{\text {th }}$ century (Lloyd, 1808) but very few papers reveal the studies on wild mushrooms from western Nepal. This is a preliminary report on ethnomycological investigation carried out at Vulkepani community forest, Rupandehi district western terai, Nepal.

The study area lies in the sacred birth place of Lord Buddha, Rupandehi district, Saljhandi VDC WN 1, Lumbini zone, southern belt of west Nepal. It encompasses $27.6854^{\circ}-27.69912^{\circ} \mathrm{N}$ latitude and $83.28397^{\circ}-83.33732^{\circ}$ E longitude. The area occupies 199.98 ha land between 262 and $476 \mathrm{msl}$. The average annual rainfall is $1391 \mathrm{~mm}(\mathrm{GoN}, 2010)$. Phygiographically the area lies typically in tropical riverine belt composed of Khair (Acacia cateachu), Karma (Adina cardifolia), Banjhi (Anogeissus latifoliya), Simal (Bombax ceiba), Satisal (Dalbergia latifolia), Sissoo (Dalbergia sissoo), Jamun (Syzygium cumini), Sindure (Mallotus philippinensis), Kandel (Phoenix sylvestris), Sal (Shorea robusta), Kusum (Schleihera oleosa), Sagwan (Tectona grandis), Asana (Terminalia alata), Barro (T. belerica) etc. (Stainton, 1972). The diverse phytodiversity and ecological conditions provide a good homeland for the growth of tremendous amount of parasitic, saprophytic and mycorrhizal mushrooms (Aryal \& Budathoki, 2012b). The northern belt of this area has loamy sand, while the southern belt consists of sandy loam to loamy soil. This is the virgin area for the mushroom investigation and study.

\section{Materials and Methods}

Altogether, 21 mushroom samples were collected, and the local informants were interviewed. Indigenous knowledge survey was conducted from 15 to 31 May 2011, and specimens were 
collected from 1 June to 31 October 2012. The Participatory Rural Appraisal (PRA) technique was adopted with the local people aimed at getting information largely on nutritional aspects. Data were obtained using combined semi-structured questionnaire, participatory discussions and field observations. Mushroom samples were photographed in their natural habitat, and their morphological characters were noted. The habit and habitat including ecological parameters viz., altitude, vegetation composition, soil type, soil $\mathrm{pH}$, soil moisture, humidity and temperature were recorded. The frequency class was calculated by the formula:

$$
\frac{\text { No. of plots in which species ' } \mathrm{x} \text { ' occurs }}{\text { Total no. of plot }} \times 100
$$

The samples were well dried and packed in wax-paper bags wrapped with aluminum foil. The paper bags were brought to laboratory of Central Department of Botany, Tribhuvan University, for further microscopic examination. The identification was done with the help of relevant literature (Balfour-Browne, 1968; Mckenenny, 1971; Dickinson \& Lucas, 1979; Pacioni, 1985; Singer, 1986; Imazeki et al., 1988; Kummar, et al., 1990; Adhikari, 2000, 2012; Hattori et al., 2002; Devkota, 2005; Payday, 2008; Christensen et al., 2008ab; Manandhar et. al., 2009) and websites (biodiversity library.org, Index fungorum, Jstor.org, Mycobank.org, Scircus, tropicos.org, Agaricus in the Pacific Northwest). The voucher specimens were deposited in Tribhuvan University Central Herbarium (TUCH), Kathmandu, Nepal.

\section{Results}

During the field survey, altogether, 21 species of Basidiomycetes belonging to 7 orders, 12 families and 14 genera were recorded with their brief descriptions (Table 1).

Table 1. Wild mushrooms collected from Vulkepani Community Forest, Rupandehi District, Nepal

\begin{tabular}{|c|c|c|c|}
\hline SN Scientific name; order; family & Local name & $\begin{array}{l}\text { Host/Substratum; } \\
\text { ecology }\end{array}$ & Application \\
\hline $\begin{array}{l}1 \text { Amanita caesarea (Scop.) Pers.; } \\
\text { Agaricales; Amanitaceae }\end{array}$ & Suntale chyau & Soil; Mycorrhizae & vegetable \\
\hline $\begin{array}{l}2 \text { Amanita chepangiana Tulloss \& } \\
\text { Bhandary; Agaricales; Plutaceae }\end{array}$ & $\begin{array}{l}\text { Salleu, kukhura } \\
\text { Phule chayau }\end{array}$ & Soil; Mycorrhizae & vegetable \\
\hline $\begin{array}{l}3 \text { Amanita pantharina (DC.) } \\
\text { Kromb.; Agaricales; Amanitaceae }\end{array}$ & Bhut chyau & Soil; Mycorrhizae & Deadly poisonous \\
\hline $\begin{array}{l}4 \text { Agaricus augustus Fr.; } \\
\text { Agaricales; Agaricaceae }\end{array}$ & Kaile chyau & Soil; Saprophytic & vegetable \\
\hline $\begin{array}{l}5 \text { Agaricus sylvicola (Vittad.) Peck; } \\
\text { Agaricales; Plutaceae }\end{array}$ & Sal chyau & Soil; Saprophytic & not edible \\
\hline $\begin{array}{l}6 \text { Auricularia auricula (L.) } \\
\text { Underw.; Auricularials; } \\
\text { Auriculaliaceae }\end{array}$ & Todke chyau & $\begin{array}{l}\text { decay log from moist } \\
\text { shady place; Parasitic }\end{array}$ & vegetable/ Soup \\
\hline $\begin{array}{l}7 \text { Cantharellus cibarius Fr.; } \\
\text { Cantharellales; Cantharellaceae }\end{array}$ & $\begin{array}{l}\text { Chyau mathi } \\
\text { seto chyau }\end{array}$ & $\begin{array}{l}\text { On Russula sp at moist } \\
\text { shady place; Parasitic }\end{array}$ & Not edible \\
\hline $\begin{array}{l}8 \text { Cpprinus Comatus (Mill.) Pers.; } \\
\text { Agaricales; Coprinaceae }\end{array}$ & Gobre chyau & Soil; Saprophytic & $\begin{array}{l}\text { Edible in young stage; dried } \\
\text { powder given to child with rice } \\
\text { or milk for good sleep }\end{array}$ \\
\hline $\begin{array}{l}9 \text { Coprinus plicatilis (Curtis) Fr.; } \\
\text { Agaricales; Coprinaceae }\end{array}$ & Payeje chyau & $\begin{array}{l}\log (\text { Acacea catechu }) \\
\text { Saprophytic }\end{array}$ & Poisonous \\
\hline $\begin{array}{l}10 \text { Macrolepiota fuliginosa (Barla) } \\
\text { Bon; Agaricales; Agaricaceae }\end{array}$ & Gobbre chyau & Soil; Saprophytic & vegetable \\
\hline
\end{tabular}




\begin{tabular}{|c|c|c|c|}
\hline $\begin{array}{l}11 \text { Pycnoporus cinnabarinus (Jacq.) } \\
\text { P. Karst.; Polyporales; } \\
\text { Polyporaceae }\end{array}$ & Sindure chyau & $\begin{array}{l}\text { Stump (Syzygium } \\
\text { cumini); Saprophytic }\end{array}$ & $\begin{array}{l}\text { Medicine, relief ear } \\
\text { pain, Mumps }\end{array}$ \\
\hline $\begin{array}{l}12 \text { Ramaria aurea }(\text { Fr.) Quel.; } \\
\text { Clavariales; Ramariaceae }\end{array}$ & Thakre chyau & $\begin{array}{l}\text { Moist shady place of } \\
\text { pine trees; Mycorrhizal }\end{array}$ & vegetable, sold in local market \\
\hline $\begin{array}{l}13 \text { Ramaria flava (Fr.) Quel.; } \\
\text { Clavariales; Ramariaceae }\end{array}$ & $\begin{array}{l}\text { Thokre } \\
\text { chyau }\end{array}$ & $\begin{array}{l}\text { Soil in pine trees; } \\
\text { Mycorrhizal }\end{array}$ & vegetable, sold in local market \\
\hline $\begin{array}{l}14 \text { Russula nigricans Fr.; Russulales; } \\
\text { Russulaceae }\end{array}$ & Handi chyau & Soil; Mycorrhizae & Edible, pickle \\
\hline $\begin{array}{l}15 \text { Schizophyllum commune Fr.: Fr.; } \\
\text { Agaricales; Schizophyllaceae }\end{array}$ & Pankha chyau & $\begin{array}{l}\text { decay wood (Shorea } \\
\text { robusta); Saprophytic }\end{array}$ & $\begin{array}{l}\text { Edible, religious, cultural, } \\
\text { culinary purpose }\end{array}$ \\
\hline $\begin{array}{l}16 \text { Scleroderma bovista. Fr.; } \\
\text { Bolatales; Sclero-dermataceae }\end{array}$ & $\begin{array}{l}\text { Alu chyau, } \\
\text { Ptteu }\end{array}$ & Soil; Mycorhizae & Vegetable, medicinal \\
\hline $\begin{array}{l}17 \text { Scleroderma citrinum Pers.; } \\
\text { Bolatales; Sclero-dermataceae }\end{array}$ & Dalle chyau & Soil; Mycorhizae & $\begin{array}{l}\text { Inedible/medicinal causes gastric } \\
\text { disorders or acute indigestion }\end{array}$ \\
\hline $\begin{array}{l}18 \text { Termitomyces clypeatus R. Heim; } \\
\text { Agaricales; Tricholomataceae }\end{array}$ & $\begin{array}{l}\text { Dhamere, } \\
\text { Vemti chyau }\end{array}$ & $\begin{array}{l}\text { Termites nest; Obligate } \\
\text { symbiont }\end{array}$ & $\begin{array}{l}\text { Edible, medicinal, fever, } \\
\text { miseales }\end{array}$ \\
\hline $\begin{array}{l}19 \text { Termitomyces eurrhizus (Berk.) } \\
\text { R. Heim; Agaricales; } \\
\text { Tricholomataceae }\end{array}$ & $\begin{array}{l}\text { Dhamere, } \\
\text { Bagale chyau }\end{array}$ & $\begin{array}{l}\text { Termites nest; Obligate } \\
\text { symbiont }\end{array}$ & $\begin{array}{l}\text { Edible, medicinal, fever, } \\
\text { miseales }\end{array}$ \\
\hline $\begin{array}{l}20 \text { Volvariella bombycina (Sch. ex } \\
\text { Fr.) Sing.; Agaricales; Plutaceae }\end{array}$ & Chiple chyau & $\begin{array}{l}\text { On wood (Adena } \\
\text { cardifolia);Saprophytic }\end{array}$ & vegetable \\
\hline $\begin{array}{l}21 \text { Volvorella volvacea (Bull.:Fr.) } \\
\text { Sing.; Agaricales; Plutaceae }\end{array}$ & Parale chyau & $\begin{array}{l}\text { decomposed paddy } \\
\text { straw; Saprophytic }\end{array}$ & vegetable \\
\hline
\end{tabular}

Notable species are Amanita caesarea, A. chepangiana, A. pantherina, Agaricus augustus, A. sylvicola, Coprinus comatus, C. plicatilis, Ramaria aurea, R. flava, Scleroderma bovista, S. citrinum, Termitomyces clypeatus, T. eurhizeus, Volvariella volvacea and V. Bombycina. Out of total collection, $62 \%$ mushrooms belonged to Agaricales order followed by Boletales, Claveriales, Auriculariales, Cantharellales Polyporales, and Russulales (Fig. 1).

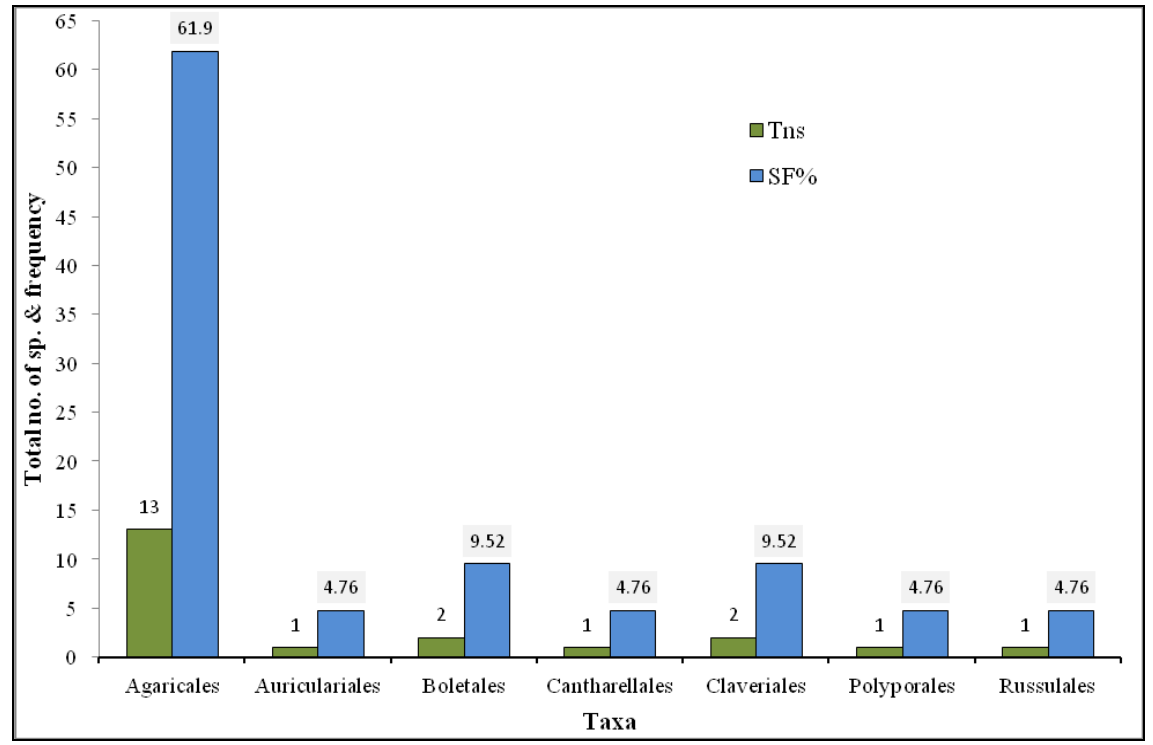

Figure 1. Total no. of species (Tns) and \% frequency of Basidiomycotina. 


\section{Nutritional value and therapeutic use}

In general, $96.5 \%$ of the mushrooms were used as food, $2.5 \%$ as medicine, $0.5 \%$ as taste and flavor, and $0.5 \%$ as tonic. People also used these mushrooms for the remedy of different types of disease and ailments. Out of 80 respondents, $25 \%$ used it for the remedy of measles, $20 \%$ yellow fever, $15 \%$ jaundice, $10 \%$ inappetence, $10 \%$ mumps, ear pain and cut wounds, $10 \%$, delivery pain, $5 \%$ constipation, $2.5 \%$ skin diseases, $1.25 \%$ muscular pain, and $1.25 \%$ stomach pain.

\section{Discussion}

The study revealed that there were plenty of species, which were edible and of medicinal value. Many mushroom species are gathered by local people for their daily livelihood and trade. The area embraces the mycophagous ethnic communities' viz., Chamar, Damaee, Dom, Gugung, Kami, Kumal, Lodh, Magar, Newar, Rai, Sarki, Tharu, Tamang, Thakali and Thakuri (DDC, Rupandehi, 2064 BS.). They pronounce the mushrooms as Bhuenphor, Bagale, Deuule (Termitomyces spp.); Salleou (Amanita spp); Patteuo, Phutuki, Dalle, Bhunke (Scleroderma spp), Gobbre (Macrolepiota spp.) etc. They sacked in bags and carried to market for sell (e.g. Scleroderma, Termitomyces, Volvorella spp.etc). The tropical species like Amanita chepangiana seem to be widespread in the terai belt of Nepal. The medicinally important tropical polypore like Pycnoporus cinnabarinusis gathered for the remedy of infectious disease (ear pain problem, mump). The cosmopolitan species like Schizophyllum commune the inedible species is sometimes used for culinary purposes in food deficit condition. This species has religious value too, and is used as 'Sagun' i.e., better happening in the marriage ceremony in Newar community. The Diptocarp inhibiting mycoelement like Scleroderma citrinum, S. bovista are used both for edible and medicinal values. Two species of Termitomyces, the tropical African element, (T. clypeatus and T. eurhizeus) prevail in this area, which are distributed from South Africa to the Indian subcontinent. Their market price fluctuates in between 5 and $6 \$ / \mathrm{kg}$.

This study also revealed that the wild mushrooms are widely used by the rural people to fulfil their basic needs and also used for therapeutic purpose. Ramaria aurea and Ramaria flava are considered as nonedible species in Japan (Imazeki et al., 1988), but they are used as food in mycophagous ethnic community of this study sites. During PRA surveys with the local people, when questioned about the changing status of the existing species, respondents listed some important species such as Auricularia auricula, Cantharellus cibarius, Macrolepiota fuliginosa, Termitomyces clypeatus, T. eurhizeus which have declined in abundance during the last two decades. Hence, efforts should be directed to conserve the valuable species and their habitats with the implementation of locally sustainable management involving local participation.

The present investigation showed that the pure stand of Shorea robusta favors the growth of numerous species of mushroom flora. The litter debris of Shorea robusta and other species of vascular flora favors the regulation and maintenance of temperature and moisture in the soil.

\section{Acknowledgments}

Nepal Academy of Science and Technology is highly acknowledged to provide the Ph.D. research grant. Thanks are also due to Central Department of Botany, Tribhuvan University for providing the laboratory facilities and Institute of Science and Technology for granting study leave. Sincere thanks are extended to local people for providing information. 


\section{References}

Adhikari, M.K. 2000. Mushrooms of Nepal. P.U. Printers, Kathmandu, Nepal. 236p.

Adhikari, MK. 2012. Researches on the Nepalese mycoflora-2 (Checklist of macrofungi (mushrooms) Siddhartha Printing Press, Lalitpur, Nepal. 90 p.

Aryal, H.P. \& U. Budathoki. 2012b. Macrofungi of Karhiya community forest, western tarai, Nepal. Nepalese Journal of Bioscience 2: 93-97.

Aryal, H.P. \& U. Budhathoki 2013b. The genus Amanita (Pers.) in Lumbini zone, Nepal. Scientific World 11(11): 113-120.

Aryal, H.P. \& U. Budhathoki. 2013a. Buchwaldoboletus lignicola (Basidiomycetes), an Inedible wild mushroom New to Nepal. Our Nature 11(1): 31-35.

Balfour-Browne, F.L. 1968. Fungi of recent Nepal expendition. Bull. Brit. Mus. (Nat. Hist.) Ser. Bot. 4: 99-141.

Christensen, M., S. Bhattarai, S. Devkota \& H.O. Larsen. 2008a. Collection and use of wild edible fungi in Nepal. Eco. Bot. 62(1): 12-23.

Christensen, M., S. Devkota \& S. Bhattarai. 2008b. Use of wild edible mushrooms in the Annapurna Conservation Area, Nepal. Jour. Mycol. Phytopath. Soc. Nep. 1: 1-6.

DDC. 2007. Rupandehi District Profile. 2007.

De Boer, W., L.B. Folman, R.C. Summerbell \& L. Boddy. 2005. Living in a fungal world: impact of fungi on soil bacterial niche development. FEMS Mycrobiol Review 29: 795-811.

Devkota, S. 2005.Mushroom Diversity In Lumle (Kaski) and Study of Clavariales from Lumle and Vicinity of Kathmandu Valley, Nepal. A Master's thesis Submitted to the Central Department of Botany, Tribhuvan University, Nepal. 114p.

DFO. 2012. District Forest Office, Rupandehi: Brief Introduction and Progress Report 2012.

Dickinson, C. \& J. Lucas. 1979. Encyclopedia of Mushrooms. Orchid Publication, London.

District Development Committee, Rupandehi, Profile 2064 BS.

GoN (Government of Nepal). 2010. Climatological and agro meteorological records of Nepal. Government of Nepal. Ministry of Environment, Science and Technology. Department of Hydrology and Meteorology, Kathmandu, Nepal.

Hattori, T., M.K. Adhikari, T. Suda \& Y. Doi. 2002. A list of polypores (Basidiomycotina, Apyllophorales) collected in Jumla, Nepal. Bull Natl Sci Mus Ser B 28(2): 27-38.

Imazeki, R., Y. Otani \& T. Hongo. 1988. Colored Illustration of Fungi of Japan. YAMAKEI Publishers Co. Ltd. Tokyo, Japan.

Kummar, A., R.P. Bhatt \& T.N. Lakhanpal. 1990. The Amanitaceae of India. Bishen Sing Mahendra Pal Singh, 23- A, Deharadun, India.

Llyod, C.G. 1808. Mycological notes. Mycology. Cincinnati, Ohio: Llyod Library \& Museum. 75p.

Manandhar, V. \& M.K. Adhikari. 2009. The family Sclerodermataceae: ectomycorhizal fungi from Nepal. Bull. Dept.Pl.Res. 31, Department of Plant Resources, Thapathali, Kathmandu, Nepal. pp. 29-34.

Mckenenny, M. 1971. The savory wild mushroom. University of Washington press, USA.

Miyamotto, T., T. Igarashi \& K. Takahashi. 2000. Liglin degrading ability of litter decomposing Basidiomycetes from Picea forest of Hokkaido. Mycosci. 41: 105-110.

Pacioni, G. 1985. The Mcdonald's encyclopedia of mushrooms and toadstools. Mcdonald \& Co. Ltd. London.

Singer, R. 1986. The Agaricales in modern taxonomy ( $4^{\text {th }}$ edition), Bishen Singh Mahendra Pal Singh, Dehradun (India).

Stainton, JDA. 1972. Forest of Nepal. John Murray Ltd., London. 181p. 